\title{
Anthropological adventures with Romania's Wizard of Oz, 1973-1989
}

\author{
Katherine Verdery
}

\begin{abstract}
Throughout the Cold War, most people in the US saw the communist party-states of the Soviet bloc as all-powerful regimes imposing their will on their populations. The author, a child of the Cold War, began her fieldwork in Romania in the 1970s in this belief. The present essay describes how her experiences in Romania between 1973 and 1989 gradually forced her to see things differently, bringing her to realize that centralization was only one face of a system of rule pervaded by barely controlled anarchy and parasitism on the state. It was not simply that the regime had failed to change people's consciousness; rather, the system's operation was actively producing something quite different. These insights contributed to the author's developing a new model of the workings of socialism.
\end{abstract}

Keywords: communism, Eastern Europe, Romania, weak states

In a special report entitled 'Death of a dictator', aired in April 1990 on the US television channel ABC News, newsman Ted Koppel leads viewers into the surveillance headquarters of the widely feared Romanian secret police, the Securitate. There he points to a modest bank of tape recorders, which (we are to believe) have been monitoring the conversations of Romania's 23 million inhabitants over the previous five decades. "So, here it is", says Koppel,

"Securitate's main listening center in Bucharest, the principal monitoring location for the Romanian secret police. It is, to put it gently, something of a let-down - rather like the scene in the Wizard of $\mathrm{Oz}$, where Dorothy pulls back the curtain to reveal not the allknowing, all-powerful wizard, but a rather frightened little man, who has inspired fear and trembling with smoke and mirrors." ${ }^{11}$

Although I doubt that the modest bank of equipment was all there was to Securitate surveillance, Koppel's conclusion aptly states one of the chief messages I drew from my 25 years of research in socialist Romania: the centralized power of the Communist Party was much overestimated. The image of potency it projected was in considerable measure illusory, like the smoke and mirrors behind the fearsome Wizard of $\mathrm{Oz}$.

It was a conclusion hard won, for like many US citizens, when I began my research in Romania in 1973 my image of the communist east was of stern, oppressive and allpowerful party-states exercising terror and coercion upon their citizens. I had chosen to 
work there not from a commitment to socialist ideals, but rather from a fascination with the totalitarian image (see Verdery 1996: 9), which governed my perception of much that happened to me during my first several trips to Romania. Only in the mid-1980s did I begin to reconsider the image in light of what I experienced daily during my research, as events set up a contradiction between the forbidding totalitarian state of my imagining and the Red Wizard of $\mathrm{Oz}$ I eventually came to see behind it.

To say this is not to deny that people suffered terrible persecution at the hands of the Romanian and other communist parties: state terror was not simply a matter of Western misperception but, for some, a devastating fact of life. By the time of my research, however, state terror - large though it loomed in my anticipation - was mainly a thing of the past. I arrived in Romania during a period of unprecedented opening. Nicolae Ceauşescu had been in power for eight years, his popularity consolidated by his having condemned the Warsaw Pact invasion of Czechoslovakia, and living standards had improved dramatically for many Romanians. Although the situation would deteriorate thereafter, I began my work when Romanian socialism was at the apogee of such favor and success as it would ever achieve. In spite of this, my image of an omnipotent party-state persisted for over a decade - testimony, in part, to the power of totalitarian propaganda not only in the US, but also in the socialist countries themselves.

In this essay I describe how my experiences as a fieldworker in Romania between 1973 and 1989 gradually forced me to change this image. I concentrate on the years 1984-5, a time of heightened austerity and surveillance - facts that paradoxically revealed the system's weaknesses with unusual clarity.

\section{Fieldwork in socialist Romania}

My fieldwork in Romania during the socialist period consisted of a total of just over three years altogether between 1973 and
1989: eighteen months in 1973-4, four in 197980, eleven in 1984-5 and five in 1987-8. Each of these trips was funded by the International Research and Exchanges Board (IREX), a US organization established in 1968 by a consortium of US universities to organize research exchanges with the Soviet bloc. ${ }^{2} \mathrm{Al}-$ though by the mid-1980s Romania would be (with Albania) the most repressive regime in the region, the early 1970s were a good time for US researchers there: the country was relatively open, and the exchange-program handbooks even listed anthropology as one of the disciplines it welcomed. ${ }^{3}$ For that reason, Romania hosted more Western anthropologists during the 1970s than any other socialist country.

Part of the exchange-program agreement was that grantees were assigned to a Romanian academic institution, with one of its scholars as research supervisor. When I first arrived in August 1973, I was assigned to the Institute of Ethnography and Folklore in Bucharest as the ward of its director, Prof. Mihai Pop. A man of extraordinary warmth and personal charm, he played an indispensable role in getting me into a village (Vlaicu) in Transylvania and smoothing my way with county and commune officials. I attribute to his interventions the relatively trouble-free experience I had during my first field trip. Although a few villagers kept their distance from me, convinced that I was really a spy, most were hospitable and receptive. I knew that commune authorities kept track of where I went if I left the village and occasionally asked my landlord how I spent my days, but no one was interrogated about my visits (in contrast to what would happen later, in 1984-5). In 1979-80 I returned to Romania again for four months, three of them in Vlaicu and one in the city of Cluj. The main difference from before was that I now heard more grumbling about regime policies, a subject on which my respondents had not been overly critical in the earlier period.

For my third visit, in 1984-5, the conditions of life in Romania were vastly different from those of my earlier visits. As of 1980, Ceauşescu's government - alarmed at 
the effects of the Solidarity movement in Poland - began imposing an austerity program designed to repay the foreign debt. Valuable manufactures and foodstuffs such as meat and eggs were exported for hard currency. The policy was ratcheted up during the difficult winter of 1984, when prolonged cold throughout Western Europe increased the demand for fuel; energy of all kinds joined Romanian foodstuffs on the road to export. Inside the country drastic fuel rationing left Romanians shivering in cold apartments and offices, unable to drive their cars, and waiting interminably for public transportation that never came (see Verdery 1992). In addition, imports were cut to improve the balance of trade, so that it now became almost impossible to find the coveted Pepsi or Kent cigarettes so essential to bribes and gifts. (The situation was so bad that even those people with enough pull to obtain a rare Pepsi at a tourist hotel might do so under cover, as I learned when a new friend took me out for a drink. The sort of guy who could always get the best thing in the house, he ordered us Pepsi, but what came was a pot of tea and two tea-cups - camouflage for the Pepsi, so the waitress might avoid trouble with other customers.) These conditions still obtained during my two brief research trips in 1987 and 1988. Because the government assumed that these conditions might rouse citizens to opposition and that an American might foment it, scrutiny of my activities during the 1980s increased dramatically, compared with before. In the house across from my room, I learned after 1989, there was round-the-clock police surveillance; worst of all, villagers I interviewed that year were debriefed by police afterwards.

Nonetheless, even in these bad times I enjoyed working in Romania, for the people I encountered in both cities and villages were marvelous company. Their buoyancy of spirit, incomparable jokes and frequent generosity in the grimmest of circumstances kept me from losing heart, and their flat rejection of Party-imposed constraints created an environment I found very invigorating. I emphasize this because in pursuing my theme of the Romanian Communist Party as Wizard of $\mathrm{Oz}$, I present some anecdotes in which this most salient characteristic of Romanians does not figure. I do not want that fact to obscure my appreciation of what so many hospitable people offered me.

\section{Socialist disorganization}

As I have said, then, I first went to Romania a firm believer in the image of a totalitarian power. I vividly remember how I felt in July 1973 as I stood on the platform in the train station in Sofia, Bulgaria, waiting for the Soviet-bound train that would take me to Bucharest (I was traveling from Greece). Night had already fallen. Suddenly out of nowhere, it seemed, a bullet-headed engine drew into the station almost without a sound, bearing a huge sign that read 'MOCKBA'. The excitement I felt was no match for the fear and dread of what the name 'Moscow' signified to me then.

Yet for a country in which the Party was supposed to have tight control over everything, Romania was a fairly anarchic place, had I chosen to notice. In my very first week there, I was invited to join four couples on their vacation at the Black Sea; they passed the week spiriting me past the hotel receptionist to keep me from being discovered as a foreigner, subject to higher room rates. What I noticed, instead, was that the Party intended to follow foreigners' every movement. Similarly, the woman I stayed with in Bucharest spent every evening with her ear glued to the radio listening to Voice of America, setting the volume very low (as she explained to me) so that her neighbors would not hear it and report her. I noticed her worry more than her subversive behavior.

An agent of my early education into the disorganized ways of Romanian socialism was the Mobra motorbike for which I paid $\$ 200$, a source of endless mirth to my Romanian acquaintances. I had walked into a special 'dollar store' for foreigners, signed the papers and paid up, expecting the bike to be brought out to me on the spot. Instead, I 
was told to go and pick it up at the factory, way off at the outskirts of Bucharest. Several bus rides and an hour or two later I arrived at the factory just before the main office closed; come back tomorrow, I was advised. Somehow I persuaded the clerk I needed the bike now, and so after an unseemly wait, I was presented with a green bike and was asked whether I had brought gasoline and a battery with me - which, of course, I had not. In retrospect, I realize I was supposed to have been bribing people at each step to smooth my acquisition of the bike, but at that point I had not yet been initiated into this most basic rule of all social intercourse in Romania. A kindly bystander gave me some gasoline from his own gas tank, and somehow a battery was 'found'; getting it charged took several more days and mounting aggravation at the discrepancy between this purchase and comparable undertakings at home. Buying the bike was my first indication that consumer satisfaction was not the driving force behind the command economy, an impression that the bike's performance repeatedly confirmed.

The ordeal of its purchase was the first of many frustrations to which this bike would expose me, frustrations similarly illuminating of disorganized Romanian socialism. Commencing with the arduous process of registering it and getting license plates (with a bright red ' $\mathrm{TC}$ ' on them, meaning 'Consular Transport' and visible at great distance), they continued with the reconnaissance trip I took on it to the county I was supposed to work in. Arriving in its capital city, Deva, I was given an itinerary organized by two of Prof. Pop's former students, now low-level apparatchiks in the county bureaucracy. As they handed me my list of contacts, they advised me cryptically, "Be careful when you get to place $X^{\prime}$ [the first stop on my tour], with no further elaboration. At place $X$, however, I was stopped by a policeman, who could scarcely miss the bright red TC license plate branding me a foreigner. Had not I seen the sign on the road, he demanded, 'Entry prohibited to foreigners?' What was I doing here? In my still-rudimentary Romanian I explained my presence as best I could, telling him about my tour of the county, the officials in the capital who had set it up, the people who were waiting for me to arrive for the night. At length he went into his office, leaving me in the hallway, and telephoned police headquarters in Deva. Because he had to shout to be heard, I could follow his every syllable, as he went from forthright to cautious to anxious to servile. He returned to tell me that it had been his mistake to stop me, that my trip was all approved and that I was to continue as planned. I asked how I could conduct a year's research if there was a sign prohibiting entry to foreigners, to which he replied that there was a military base up the road, but if I had permission to be here... When I insisted that I ought to turn right around and go back to Deva, he became alarmed and said I must continue, for my trip had been arranged by the authorities. He insisted so ardently that I at length complied.

What impressed me in this episode at the time was the degree of surveillance, the fact that by calling county headquarters he had found an officer who knew who I was and where I was supposed to be. What I overlooked was the holes in the chain of command: somehow no one had communicated downward to the local police the information that I was to be allowed to ride my motorbike into a restricted military zone. As I negotiated with the policeman, it escaped my notice that he was desperately trying to cover up this failure, even revealing the location of the military base as he did so. In a word, the episode revealed that while control may have been well orchestrated at the center, it was poorly coordinated with levels below. I was more receptive to the former conclusion than the latter.

The same was true on many other occasions, such as when I arranged to have a set of nude photographs taken by a photographer who turned out to work in the so-called Scînteia building (Casa Scînteii). This humongous and forbidding structure of quintessential Stalinist type housed the Communist Party daily newspaper, Scînteia, along with some other major newspapers, some 
publishing houses and a government ministry or two. When I realized that this was where I was supposed to take off all my clothes and be photographed, I was struck dumb, but my photographer did not seem to feel there was anything problematic about it. Once again, instead of noticing that in this bastion of communist propaganda it was possible for a photographer employed by the Communist Party paper to take nude photos of an American and to do so with nonchalance mixed with only a little nervousness, I terrified myself with the thought of what the powerful communists would surely do to us if we were caught. I did not consider that he judged the likelihood of trouble as small enough to permit him to take the chance, but was instead overwhelmed by the look of the building and what I believed it represented: power and repression incarnate. Thus, I failed to note in this episode the serendipity, if not the outright laxness, of central control over Romanians' activities.

\section{The 'new socialist man'}

Despite my respect for the rigors of surveillance, I had plenty of other evidence that socialist control was far from absolute. For one thing, there was the obvious lack of anything resembling socialist consciousness among most of the people I dealt with. Somehow I had imagined that Communists brainwashed their subjects into believing all their propaganda; it did not take long to give the lie to that notion. Although few villagers among whom I spent most of my time during the 1970s expressed criticism of the regime, this was not true of people I met in towns and cities, who criticized it endlessly. Only much later did I began to see these complaints as part of a 'lamenting' pattern often used with foreigners (cf. Ries 1997); at the time I found them startling evidence of unreconstructed mindsets, of the regime's failure to produce the much-trumpeted 'new socialist man'.

Perhaps my first lesson in this respect came within a month of my arrival, on August 23 - the holiday marking Romania's 'liberation from the fascist yoke' in 1944. Since I knew this was supposed to be a major Communist Party event marked by an immense parade, I thought I should witness it close up; I asked my official contact at IREX's partner office if I could sit in the bleachers at Piata Aviatorilor, where Party officials and other dignitaries would review the parade. He regretted that there was too little time to arrange this and advised me simply to watch the parade from the sidewalk. Meanwhile, when I asked my acquaintances about their plans, they surprised me by saying they would get as far away from the parade as possible - take a trip to the beach, the mountains... August 23 meant, for them, not a celebration of communism but a chance to escape. No one had any interest in accompanying me to the parade or explaining why August 23 was such an important date. I would have to carry out my anthropological research method of 'participant observation' on my own.

That afternoon, dressed in my usual nondescript outfit except for the enormous camera I carried in a canvas handbag, I headed off for the parade route. Emerging from a side street onto the main boulevard, I started walking along the sidewalk parallel to the parade in the street. Suddenly, I was accosted by a grubbylooking man wearing a red armband that said Ordine (Order): his job was to keep the crowd in line. "Get back into the parade", he snarled. My Romanian was inadequate to explaining what I was trying to do, so I did what he ordered - joined the parade. I fell in with a group of young men in their twenties, who responded to my asking, "Where are you from?" with [residential] sector 2 and the name of a factory. When they returned the question and I answered "California", a ripple of excitement spread through our portion of the otherwiseapathetic crowd. One of my companions eagerly offered me his plastic flower to hold aloft as we passed in front of Ceaussescu in the reviewing stand; he was relieved not to have to carry it himself. We had now arrived at the edge of the square, and a man with a bullhorn was trying vainly to whip the crowd into some semblance of enthusiasm for slogans like "Ceauşescu - PCR [Romanian Communist 
Party]"; the response was a tepid, embarrassed chanting that turned immediately to muttering and complaint as soon as we had passed the group of dignitaries. I had just had my first direct experience with the revolutionary fervor of the Romanian proletariat.

Even I, raised in a Republican-voting household, seemed to have more socialist consciousness than those around me. For instance, one day in 1974 I sat in the kitchen of my closest village friend and her neighbor, two women then in their fifties, while they expressed their contempt for Gypsies as people who are lazy and whose work, when they do it at all, is shoddy. For these two women, those qualities were innate to Gypsies as a race. I began to argue, explaining heatedly that people in certain structural locations are deprived of the opportunity to develop the qualities my companions admired and that with an end to racist discrimination, Gypsies would show themselves as industrious as anyone else. At this, one of the women turned to the other and remarked, "She's more of a socialist than we are!" It was then that I began to understand the limitations of the 'Vanguard-Party' approach to building socialist consciousness.

Then there was 'socialist reciprocity', ranging from the simple exchange of favors between friends, kin, or acquaintances to outright bribery. I never wholly mastered this form, but as I attempted to do so it began to dawn on me that these practices were both subverting the purposes of socialism and manifesting people's lack of socialist ethics. Parents, evidently assuming that merit would not be rewarded, worried about how to influence the examiners for university entrance so their children might succeed; consumers strove to evade the stringency of socialist redistribution by working out arrangements with saleswomen in stores; friends, relatives, people born in the same place and school classmates all arranged things for one another; clerks in all manner of offices subverted socialist policies for wage equity by providing the required services only for an extra sum. So much for the premise of equality, I observed to a friend in the Ethnography Institute. She disagreed: "The wonderful thing about socialism is that unlike in your country, where 'no' always means 'no', in socialism no door is ever definitively closed. We can always figure out how to get through them if we just try."

Time spent in Romania meant innumerable encounters with just this principle. An art in which Romanians truly excelled, getting around the system was something in which they took great pleasure. For example, at the end of my stay in 1984-5, I decided to buy an oriental carpet with the sizable remnants of my research stipend. Having found a nice carpet that cost a good bit of money, I suddenly realized I had a problem: at our departure, grantees were allowed to take with us goods totaling no more than 10 per cent of our total fellowship income for the year, and my rug alone put me well over that limit. I would have to present receipts for all of my purchases as well as an affidavit from IREX's exchange partner, confirming my salary. Thinking out loud, I explained my difficulty to the clerk at the store. "No problem", she replied, "I'll just break the purchase price into two halves and give you two receipts for the rug. You throw away one and present the other at the airport. Will that do?" Although the clerk was doubtless pleased that I gave her a fat tip for her advice, it was clear that she had offered the idea simply because it was fun to outwit the authorities. We ended our transaction in wonderfully high spirits. ${ }^{4}$

Much later, I came to see these forms of reciprocity not as 'failures' of socialism but as fundamental to its operation (see, e.g., Verdery 1996: chap. 1). Similarly, what I first saw as a lack of 'socialist consciousness' I would come to understand as a result of socialism's workings: it was not simply that the regime had failed to produce new socialist men, but that the system's operation was actively producing something quite different, as I will now explain.

\section{Austerity and anarchy}

So far I have been organizing my tale around an image of 'innocence abroad'. I started my 
work in Romania knowing very little about either Romania or socialism, other than that both were supposedly totalitarian. I tended to find repression in events that could also be interpreted in other ways, and when I found evidence that Party control was not absolute, I tended to see the reason as nothing more than resistance and subversion, rather than finding therein a more complex logic. What served to 'open my eyes' and encourage a slightly different understanding were the grim conditions I encountered during my fieldwork in 1984-5, as I described them earlier. Perhaps because a social system reveals its soft underbelly more dramatically when it is in extremis than at other times, I began to see aspects of life in Romania in a new way.

The project for my year's research concerned the role of history-writing in national consciousness. As my work progressed, however, I found myself increasingly interested in the broader domain of intellectual production as it was then unfolding within the new austerity program, which aimed to cut bureaucratic costs, particularly in the domain of culture. More and more sectors of activity were cast adrift into 'self-financing', where they were supposed to develop other sources of support besides state subsidies. Museums no longer received their accustomed full support, publishing houses and cinemas and literary magazines were supposed to make it on their own, and there was much-heightened competition for access to those limited central funds that were still to be disbursed. Pursuing my project not just in Vlaicu but in academic libraries, I spent much of the year living in the Continental Hotel in Cluj, where my every movement was visible.

The year 1984-5 marked the bicentennial celebration of a Transylvanian peasant uprising, led in $1784-5$ by a peasant named Horea. This was a significant event in the history of Romanians, and it became even more so with the Party's fetish for round-number commemorations. As I have described elsewhere (Verdery 1991: chap. 6; Simmonds-Duke 1987), the year was packed with Horea events: novels, plays, student discussion groups, newspaper stories, museum exhibits, historical symposia and evening extravaganzas at Houses of Culture. At first I assumed that they had been ordered up from some ministry in Bucharest, but conversations with a few of the people behind such events (some historians, a museum director, a publisher and so on) led me to think otherwise. Discussing with a museum director, for example, the 'Horea spectacular' he had sponsored the evening before, I asked him who had told him to do this: "No one!" he replied, adding that he had figured the Horea bicentennial would be a good way to find some extra money and visibility for his museum, whose revenues from regular visitors were evaporating.

As I pursued this line of inquiry, I learned that others thought like this man. Enterprising members of History Institutes applied to the Party's Culture Committee in the various counties, gambling that the Party would find money for symposia on this subject and that the organizers would gain notice for their patriotism in honoring such an important Romanian hero. Novelists and playwrights profited from Horea, as did their publishers, all presenting themselves as promoters of the national history. It seemed as if myriad Romanians, far from being directed by the Party to enact its dictates, had colonized it, taking advantage of its obsessions, and were busily making their careers on its back (see Simmonds-Duke 1987: 214-5).

This insight into the world of cultural production reoriented my interpretation of my daily experience as a participant-observer in Romanian society. I became more attentive to the ubiquitous signs of anarchy that both belied the Party's pretensions of control and were the active consequence of its attempts to exercise that control. In 1984 the straitened circumstances of people's existence made their survival strategies more visible and more daring: everyone vied for resources they could fasten onto, whether these might come from the state directly (such as goods one could sell from one's workplace) or indirectly (such as opportunities for career-building around famous heroes), from kin and friends (such as food grown in villages, or 
places to board one's children in town), or from free-floating sources such as foreigners like me. Perhaps the desperation to which Romanians were driven by Ceauşescu's austerity policies in the mid- to late 1980s made unusually clear how their adaptations were eroding Party power precisely when it seemed most oppressive.

From my vantage point as a prisoner of the Continental Hotel, I both witnessed and participated in many of these survival strategies. I selected one of the head waiters in the hotel restaurant and made him my conduit to food from the kitchen. I always paid him for it (who knows what he did with the money), and I got reasonably good things to eat when this was by no means an easy accomplishment. If friends invited me to dinner, I had a source for the special salami or delicious smoked pork tenderloin that my hosts would otherwise not find or not be able to afford. The other waiters soon learned that I was the protégée of their boss, so they were less likely to cheat on my bill if they served me breakfast, and they might supply my needs if he were off duty. The premise of this set of arrangements, of course, was that waiters had access to delicacies that normal people did not, and that they were happy to serve others through their good fortune - at evident cost to their socialist enterprise, which likely received nothing for the food I procured from it.

My relationship with one of the hotel switchboard operators was somewhat more sinister. Since my phone calls could so easily be monitored, I made few from my room, chiefly to people who were on my official list of contacts. After one lengthy call to the IREX contact in Bucharest soon after I had settled into the hotel, my phone rang. It was the switchboard operator: "Your call was 10 minutes, but I charged you for only 7." She made some small talk, then suggested I come up to meet her sometime. When I replied that I thought no one was allowed in the switchboard office but the operators, she said I should just sneak in when no one was looking. Curious, a while later I went up. She invited me to sit, then told me that I owed her some money for the minutes she had not charged to my room - she was giving me a lower rate per minute than I would otherwise have had to pay and she did not add on the 15 per cent hotel charge, so it was a good deal for both of us, she said. Seeing no alternative, I paid her the money. On another occasion, she called to ask whether I would not like to say hello to my mother in the US, cheap. She made the connection immediately (this was almost unheard of), and when I went up later she presented me with a very large bill, nonetheless smaller, she insisted, than it would have been officially.

Over the next several months, this operator extorted from me not only cash for uncharged phone minutes but pounds of coffee and whole cartons of cigarettes, for which she begged me when her son got into trouble with the police and needed a suitable 'gift'. My own participation in this scam had several motives. First, I wanted to be able to count on good service when I needed to make a call, once I saw what hours of exasperation could be spent waiting for a connection out of town. Second, I was learning interesting things from this woman about how the 'informal economy' worked, things that made me a more cautious hotel guest when I stayed in other establishments. For example, she explained to me the source of the minutes she could 'give' at cut-rate. The switchboard equipment automatically timed all calls made, so she was not actually giving me minutes that no one knew about. Many foreigners stay in this hotel, she said, and they make phone calls, sometimes abroad. By adding 30 or 60 seconds to the bill for those calls, she gradually accumulated her own minutes: other guests had already paid for them on the hotel bill, and now she could sell them for herself. For her, I was a miracle: someone who would stay a long time and thus prove a regular client for her accumulated minutes (as long as I would also make calls, something I at first resisted doing).

Third, I continued in this game because I admired her ingenuity in setting up the whole thing, ensnaring me in it and thereby solving her life-problems in a way that a 
person cooped up all day away from face-toface contact cannot easily do. While at first I had thought of her as chiefly a Securitate agent who would report all of my calls (what police organization would not want in its pocket the person with direct access to foreigners' phones?), I now saw her as someone who had her own life-problems to resolve. Like everyone else, I realized, she had turned her state job into a base for subverting the Party-state's purposes, in pursuit of her own needs and plans.

It was in this light that I began to reconsider certain kinds of events that had always seemed to instantiate the Party's power most unequivocally: surveillance and intimidation connected with my presence. When I learned about how the police - one man in particular - were disrupting my 1984 research back in my village, I began inquiring about this policeman and learned that he was heavily involved in black-market theft of timber from the forestry division in the nearby hills. Loggers would load their trucks with wood from state forests and drive down at night through the commune center - there was no other road out - to sell the stolen timber on the sly. They had bribed this policeman, who would tip them off as to when he would be on night duty, and he would sign their falsified papers and let them through. According to the logger who told me this story, that policeman was in it up to his neck, and if he were ever caught, he would be in very big trouble. Suddenly his zealous surveillance of me made sense: if he were arrested, he could point to the dossier in which he had recorded all his 'evidence' of my spying and other illegalities, and perhaps present himself as the super-patriot who kept that infamous American from destroying Romania. Given how crucial I was to his black-market livelihood, he did not actually require orders concerning me: he had his own good reasons to keep me under close guard. ${ }^{5}$

This interpretation also cast new light on other episodes in which my friends had been called before the police and asked to report on me. It was not necessarily that the AllPowerful Party had ordered them to do so: the police, too, had their Five-Year Plan, their activity targets, their career ambitions and their sins to hide. I think I was a godsend for local police and the county Securitate. I was their meal ticket, a resource to be exploited rather than merely someone they had been ordered to watch. ${ }^{6}$ To realize this was not to say that the Party had no power at all, but rather to shift the emphasis: to see its power as much more dispersed, as based in people's appropriation of the opportunities it afforded rather than in its capacity to compel people to do its will. Jan Gross (1988) describes this notion of the party-state's power with the concept of the 'spoiler state'. Using as his example the phenomenon of denunciation, Gross argues that by making the means of terror widely available, the 'spoiler state' of Stalinism made everyone complicitous with it. In this way, it produced subjects who reveled in turning the instruments of rule to their own purposes. Sometimes these purposes might further the exercise of rule, but often they subverted it, perhaps especially when the people who turned those instruments to the service of their own projects were the Party's agents themselves - policemen, local officials and so on. It was they who knew most surely that Party control rested on an illusion, for they were the Wizard of $\mathrm{Oz}$.

The closest I came to witnessing firsthand the alienation of these very people from the system they ostensibly served was in a conversation sometime during this same 1984 research trip. One day I had planned to meet a colleague for lunch. When I arrived I found him in the company of two other men, one of whom, Mr. A., was known to me as the former number 3 man in the Communist Party leadership of that county (I had met him a couple of years earlier). About two months before this lunch, he had been summarily expelled from his high post and assigned to some trivial directorship. Now here he was, a virtual nonentity, having lunch with his university friend, a US anthropologist and another man of no particular status. The waitress brought us some hot tea; testing it, I burned my lips and hastily 
put it down, but our erstwhile apparatchik Mr. A. tossed back a large swallow. "How could you do that?!" I asked in amazement, to which he replied: "My throat is well trained from shouting slogans." During our lunch he aroused much mirth with frequent sotto voce remarks of this kind, including one whose prescience would be revealed only five years later. The men were discussing the recent demotion of Ion Iliescu (who was to become Romania's first president after 1989) from yet another central Party post. One of them observed that Iliescu was finished, for 'like water' he was moving inexorably downhill. To this Mr. A. replied with mock gravity, "That just shows you don't understand the dialectics of water." It was doubtless true, of course, that this man's manifest disaffection was linked with his removal from power. What surprised me, rather, was that he would speak this frankly with a foreigner and in the presence of two other Romanians, at the height of such a repressive period. It made me wonder how many other apparatchiks might be similarly embittered, cynically manipulating the reins of power to create the illusion of its effectiveness.

\section{Conclusion}

Born in 1948, I was a typical Cold War child. The Iron Curtain was invented shortly before my birth. The McCarthy hearings took place during my formative years. Although I was not exactly keeping track of the daily news then, I must have imbibed the atmosphere to some extent, for when Sputnik was launched in 1957, I clearly recall sensing the astonishment and worry among adults around me that somehow 'the Commies' had gotten ahead of us. I remember the same anxious reception of news about the U-2 incident, the Cuban missile crisis and Khrushchev's performance with his shoe as he vowed, "We will bury you!" My parents voted Republican and my father, in particular, was overtly anti-communist. No surprise, then, that I should grow up thinking of the communist world as ruled by a fierce and diabolical power, a totalitarian state, initially frightful like the Wizard of $\mathrm{Oz}$ and (as I grew older) even more sinister and evil.

It took years of exposure to Romanian society for me to modify this view, just as it took US political science years to reconsider its totalitarian model. This exposure was in part simply from living day to day in Romania, trying to buy train tickets, obtain food, make phone calls and do all those other things that required more thought and ingenuity there than they did at home. But my reassessment of the nature of the party-state coalesced as a result of my research on the politics of intellectual and cultural production. From this work, together with my daily pursuits, I gradually came to see socialist Romania not as the fiefdom of an omnipotent party-state but as host to contradictory centralizing and anarchic forces, the anarchy every bit as crucial to the outcome as was the centralization. Groups and individuals in all areas of life became parasites on the partypolitic, pursuing their daily requirements and their careers by milking the party-state and eroding its effective centralization as they did so. This was not a party whose power was concentrated at the top - though there was indeed effective and often vicious action taken there - but one in which elements of the apparatus of power were made widely available. Police intimidation worked more significantly by being believed in than through actually being applied, ${ }^{7}$ and when it was exercised, the reason might be no grander than the careerism of some lowly officer. A Wizard of $\mathrm{Oz}$, indeed.

In offering these personal reflections on my research during the socialist period, I have emphasized the question of party power in socialist Romania because my ruminations on that theme pervaded both my research and my personal existence; it was a subject that held a thoroughgoing fascination for me. I cannot claim that my ruminations enabled me to predict the collapse of communist-party rule in the East bloc in 1989, nor that I was alone in my assessment - one shared with people like Casals (1980), Gross (1988), Rév (1987) and Shue (1988), all working towards a 
more satisfactory understanding than the obsolete totalitarian model of before. Nonetheless, as a result of my thinking about the nature of the party-state, I was perhaps less surprised by that collapse than I might have been otherwise, for I had at least an inkling of the smoke and mirrors behind the Romanian Communist Party's appearance of absolute power.

\section{Acknowledgements}

My thanks to Phyllis Mack for her contributions to this essay.

\section{Notes}

1. ABC News, 'Death of a dictator', with Ted Koppel, aired April 2, 1990.

2. IREX was funded by private foundations such as Ford and Rockefeller, as well as by the US Congress through its Title VI and Title VIII programs. For more information on IREX, see its web site at http://www.irex.org/about/ history.asp.

3. This was partly from the Romanian government's mistaken belief that the label referred largely to work in physical anthropology, as was the case with the Romanian discipline of antropologie. The kind of research that US anthropologists usually conducted fell somewhere between Romanian disciplines labeled etnografie and sociologie; there was no field comparable to US-style socio-cultural anthropology.

4. The story had one more chapter, for as I put together all of my papers in Bucharest to prepare for my departure, I realized that my other purchases for the year had put me over my 10 per cent limit. The person who administered my grant offered to write me a false statement of my income, declaring it to have been much larger than it actually was, so that my 10 per cent threshold was now high enough to cover all my purchases.

5. Tina Rosenberg (1995) and Timothy Garton Ash (1997) make similar points about the secret services of other Eastern European countries.

6. I received interesting confirmation of this possibility in 1996. Although I had imagined that the events of 1989 in Romania might lessen the surveillance over me, I found that this was not so. In 1993-4 I went to Vlaicu to begin a new project on decollectivization. When I returned in 1996 to continue it, three of my friends reported having been approached during my absence by the Securitate operative in the nearby town of Orăştie, who wanted to know what I had been up to. I also learned in my first week in 1996 that a local policeman had come around inquiring whom I was speaking with and what I was discussing; he told people I had come to spy on the local elections, which were just then being held! On the advice of a friend in Bucharest who was then in Parliament and had the personal telephone number of Virgil Măgure$\mathrm{anu}$, then head of the Romanian Information Serve (SRI), the successor of the Securitate, I telephoned Mr. Măgureanu and made an appointment to see him. (Interestingly, when I met him on the steps of the government building, he asked whether I preferred to go indoors or talk outside.) I explained that I had hoped I would be of less interest to the local police and Securitate after 1989 but had lately been finding rather the opposite. His reply to my story was, "I doubt that it's directed from here" ( $и$ cred că e pe linia noastră). When I said that I realized this but thought it important for him to know what was being done in the name of his organization in the provinces, it seemed to me that we both understood the potential for local officers to exceed their mandate.

7. I underscore, again, that I refer to Romania as of the 1970s, not earlier.

\section{References}

ABC News 1990. Death of a dictator. Special Report with Ted Koppel (aired April 2).

Casals, Felipe Garcia [Pavel Campeanu] 1980. The syncretic society. White Plains, New York: M.E. Sharpe.

Garton Ash, Timothy 1997. File: a personal history. New York: Vintage Books.

Gross, Jan T. 1988. Revolution from abroad: the Soviet conquest of Poland's Western Ukraine and Western Byelorussia. Princeton: Princeton University Press.

Gross, Jan T. 1989. Social consequences of war: preliminaries to the study of imposition of 
communist regimes in East Central Europe. East European Politics and Societies, 3: pp. 198-214.

Rév, István 1987. The advantages of being atomized. Dissent, 34: pp. 335-50.

Ries, Nancy 1997. Russian talk: culture and conversation during Perestroika. Ithaca, New York: Cornell University Press.

Rosenberg, Tina 1995. The haunted land: facing Europe's ghosts after communism. New York: Random House.

Shue, Vivienne 1988. The reach of the state: sketches of the Chinese body politic. Stanford, CA: Stanford University Press.

Simmonds-Duke, E.M. 1987. Was the peasant uprising a revolution? The meanings of a struggle over the past. Eastern European Politics and Societies, 1: pp. 187-224.

Verdery, Katherine 1991. National ideology under socialism: identity and cultural politics in Ceausescu's Romania. Berkeley and Los Angeles: University of California Press.

Verdery, Katherine 1992. The 'etatization' of time in Ceauşescu's Romania. In: Henry Rutz (ed.), The politics of time. Washington DC: American Ethnological Society: pp. 37-61 (American Ethnological Society Monographs, Number 4). Verdery, Katherine 1996. What was socialism, and what comes next? Princeton: Princeton University Press. 
